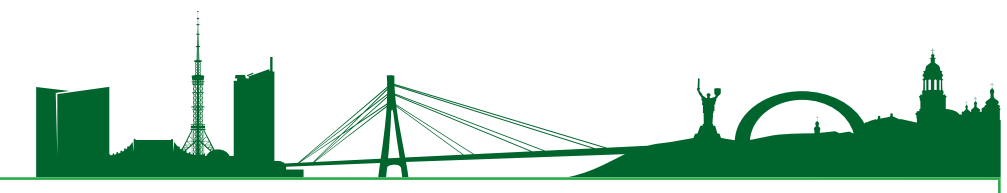

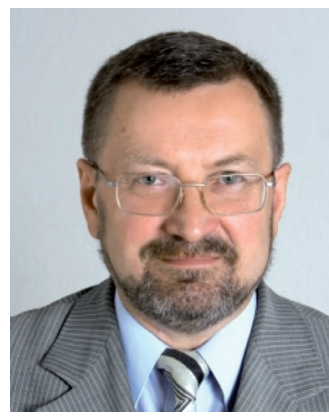

ТРОФИМЧУК О.М.

Член-кореспондент НАН України, д-р технічних наук, проф., директор, Інститут телекомунікацій і глобального інформаційного простору НАН України,

м. Київ, Україна,

e-mail: itelua@kv.ukrtel.net,

тел.: +38 (044) 245-87-97,

ORCID: 0000-0003-3782-4209

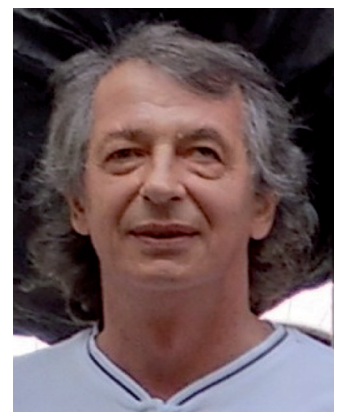

ГОМІАКО О.М.

Д-р фізико-математичних наук, проф., пров. науковий співробітник, Інститут телекомунікацій i глобального інформаційного простору НАН України,

м. Київ, Україна,

e-mail: alex@gomilko.com,

тел.: + 38 (044) 453-26-54,

ORCID: 0000-0002-4915-1120

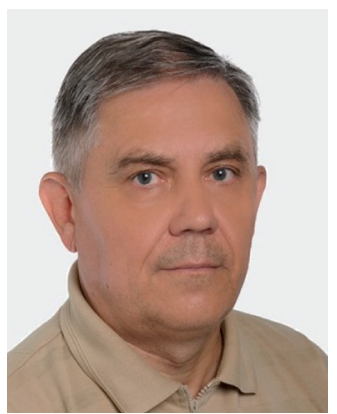

\title{
САВИЦЬКИЙ О.А.
}

Д-р технічних наук, ст. науковий співробітник, Інститут телекомунікацій i глобального інформаційного простору НАН України,

м. Київ, Україна, e-mail: osavitsky@ukr.net, тел.: + 38 (044) 453-26-54,

ORCID: 0000-0002-9212-1744

\section{ВЕРТИКААЬНИЙ ІМПЕДАНС ФУНДАМЕНТУ НА ШАРІ ВОДОНАСИЧЕНОГО ГРУНТУ}

\begin{abstract}
АНОТАЦІЯ
Один 3 методів динамічного аналізу відповідальних споруд - застосування імпедансних чи передаточних функцій частоти, які можуть бути включені до динамічних розрахункових схем будівель, що проектуються. На основі аналізу традиційних та сучасних методів визначення характеристик динамічної взаємодії фундаментів споруд 3 грунтовою основою пропонується для оцінки залежності реакції по підошві фундаменту від частоти у випадках водонасичення пористого незв'язного грунту в основі та горизонтальношаруватої його неоднорідності використовувати хвильові рівняння руху грунтової пористопружної насиченої стисливою і в'язкою рідиною основи (модель Біо двофазного середовища). Методом інтегральних перетворень визначаються символьні вирази точного розв'язку для переміщень фаз на границі основи (під підошвою фундаменту) від розподілених вертикальних гармонічних навантажень на фази. При вертикальних коливаннях малозаглибленого фундаменту (смуги) розглядаються складові реакції з боку твердої пористої та рідинної порової фаз. Функції імпедансу для жорсткої полоси 3 непроникною для порової
\end{abstract}

рідини підошвою на шаруватій пористопружній насиченій рідиною (ППНР) основі знаходяться 3 розв’язку динамічної контактної задачі методом ортогональних поліномів (при поліноміальних розкладаннях реакцій фаз з урахуванням особливостей на контакті) і оригінального програмного забезпечення по заданих геометричним i фізико-механічним параметрам фундаментів та моделі основи. На числових прикладах показано, як реакція (імпеданс) ППНР основи відрізняється від реакції пружного півпростору, а взаємодія між фундаментом 3 недренованою підошвою i водонасиченим грунтом неоднобічна внаслідок змінного (до знаку) тиску порової рідини у пружній пористій матриці під підошвою. Визначаються резонансні частоти для моделі одношарової основи з затисненою тильною гранню в залежності від висоти шару, ширини фундаменту і властивостей матеріалу двофазної основи.

КАЮЧОВІ СЛОВА: динамічна взаємодія фундаменту з грунтовою основою, водонасичений грунт, модель Біо, шарувата основа, функція імпедансу, динамічна контактна задача, метод ортогональних поліномів. 


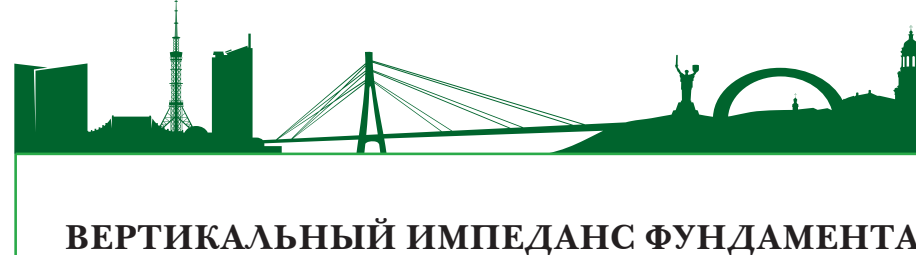 НА САОЕ ВОДОНАСЫЩЕННОГО ГРУНТА}

ТРОФИМЧУК А.Н. Член-корреспондент НАН Украины, д-р технических наук, проф., директор, Институт телекоммуникаций и глобального информацийного пространства НАН Украины, г. Киев, Украина,

e-mail: itelua@kv.ukrtel.net,

тел.: +38 (044) 245-87-97,

ORCID: 0000-0003-3782-4209

ГОМИлко А.М. Д-р физико-математических наук, проф., вед. научный сотрудник, Институт телекоммуникаций и глобального информационного пространства НАН Украины,

г. Киев, Украина,

e-mail: alex@gomilko.com,

тел.: +38 (044) 453-26-54,

ORCID: 0000-0002-4915-1120

САВИЦКИЙ О.А. Д-р технических наук, ст. научный сотрудник, Институт телекоммуникаций и глобального информационного пространства НАН Украины,

г. Киев, Украина,

e-mail: osavitsky@ukr.net,

тел.: +38 (044) 453-26-54,

ORCID: 0000-0002-9212-1744

\section{АННОТАЦИЯ}

Одним из методов анализа колебаний ответственных сооружений является использование импедансных или передаточных функций частоты, которые могут быть включены в динамические расчетные схемы проектируемых строительных объектов. На основе анализа традиционных и современных методов определения характеристик динамического взаимодействия фундаментов сооружений с грунтовым основанием предлагается для определения зависимости реакции по подошве фундамента от частоты в случаях водонасыщения пористого несвязного грунта в основании и горизонтально-слоистой его неоднородности использовать волновые уравнения движения грунтового пористоупругого насыщенного сжимаемой вязкой жидкостью основания (модель Био двухфазной среды). Методом интегральных преобразований определяются символические выражения точного решения для перемещений фаз на границе основания (под подошвой фундамента) от распределенных вертикальных гармонических нагрузок на фазы. При вертикальных колебаниях малозаглубленного фундамента (полосы) рассматриваются составляющие реакции со стороны твердой пористой и жидкой поровой фаз. Функции импеданса для штампа с непроницаемой для поровой жидкости подошвой на слоистом пористоупругом насыщенным жидкостью (ПУНЖ) двухфазном основании определяются из решения динамической контактной зада- чи методом ортогональных полиномов (при полиномиальных разложениях реакций фаз с учетом особенностей на контакте) и оригинального программного обеспечения по заданным геометрическим и физико-механическим параметрам фундаментов и модели основания. На численных примерах показано, как реакция (импеданс) ПУНЖ основания отличается от реакции упругого полупространства, а взаимодействие между фундаментом с недренированной подошвой и водонасыщенным грунтом неодностороннее вследствие переменного (до знака) давления поровой жидкости в упругой пористой матрице под подошвой. Определяются резонансные частоты для модели однослойного основания с защемленной тыльной гранью в зависимости от высоты слоя, ширины фундамента и свойств материала двухфазного основания.

КАЮЧЕВЫЕ СЛОВА: динамическое взаимодействие фундамента с грунтовым основанием, водонасыщенный грунт, модель Био, слоистое основание, функция импеданса, динамическая контактная задача, метод ортогональных полиномов

\section{THE VERTICAL IMPEDANGE OF THE FOUNDATION ON A WATER-SATURATED SOIL LAYER}

TROFYMCHUK O.M. Dr., Prof., Director, Institute of Telecommunications and Global Information Space of the NASU,

Kyiv, Ukraine,

e-mail: itelua@kv.ukrtel.net,

тел.: +38 (044) 245-87-97,

ORCID: 0000-0003-3782-4209

HOMILKO O.M. Dr., Prof., Leading Researcher, Institute of Telecommunications and Global Information Space of the NASU,

Kyiv, Ukraine,

e-mail: alex@gomilko.com,

тел.: +38 (044) 453-26-54,

ORCID: 0000-0002-4915-1120

SAVYTSKYI O.A. Dr., Prof., Senior Researcher, Institute of Telecommunications and Global Information Space of the NASU,

Kyiv, Ukraine,

e-mail: osavitsky@ukr.net,

тел.: +38 (044) 453-26-54,

ORCID: 0000-0002-9212-1744

\section{ABSTRACT}

The impedance or transfer frequency functions are used in the analysis of responsible constructions oscillations in the dynamic computational schemes of designed construction projects. Traditional and modern methods of the characteristics definition for the buildings bases dynamic interaction with the soil basis (kinematic soil-structure interaction) are analyzed. The task of finding the foundation base 


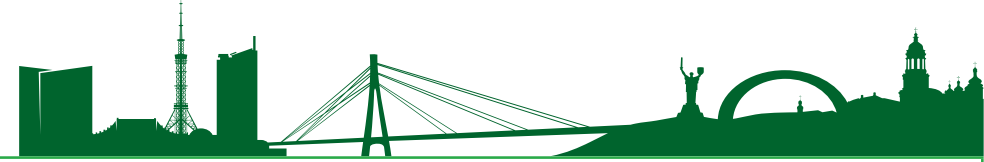

response dependence on the frequency in the cases of porous liquid-saturated non-cohesive soils (when using the Biot's soil model of the two-phase media) with horizontally layered inhomogeneity is set. The corresponding wave equations of the movement of the ground base as the porous flexible liquidsaturated (with viscous compressible liquid) media are considered. The symbolic expressions for the exact solution for phases movements at the base border (under the foundation base) caused by the distributed vertical harmonious loads on the each phase are defined by the integral transformations method. The reaction components of the solid and liquid porous phases are considered at vertical oscillations of the shallow base (a rigid strip in two-dimensions).

The impedance functions are determined from the dynamic contact problem solution. The contact reactions distributions (taking into account the theoretical features) are defined by support functions with the orthogonal polynomials method use. Original software is created for the impedance func-tions calculation by means of the set of the geometrical and physical-mechanical parameters of the foundations and base model. It is shown by numerical examples that the liquid-saturated basis reac-tion (impedance) differs from the elastic halfspace reaction, and the interaction between the foundation with an undrained base and water-saturated soil is not unilateral because of the variable (to a sign) pressure of porous liquid in an elastic porous matrix under a base. The resonant frequencies for the singlelayer base model with the jammed back side are determined depending on layer height, foundation width and two-phase base material properties.

KEY WORDS: dynamic soil-base interaction, watersaturated soil, Biot's model, layered base, impedance function, dynamic contact problem, orthogonal polynomials method.

Взаємодія малозаглиблених фундаментів, бетонних гребель, плит укосів водо- та інших сховищ, полотна цементобетонних автодоріг та ін. 3 грунтовою основою активно відбувається при динамічних впливах. При сейсмічних та техногенних динамічних діях на системи плитагрунт, споруда-грунт необхідно виконувати співставлення розрахункових домінуючих частот основи, споруди та динамічного навантаження, передбачати трансформацію сейсмічних дій, оцінювати амплітудно-частотні залежності для зміщень і реакцій, діапазони зміни контактних тисків та реактивних зусиль на підошві, враховувати можливі додаткові осідання для оцінки міцності та стійкості системи фундамент - основа. Для забезпечення сейсмостійкості споруд згідно [4] основними методами врахування сейсмічних впливів залишається коефіцієнт динамічності, а для детального аналізу - спек- тральний метод та прямий динамічний розрахунок з урахуванням комплексів аналогових акселерограм.

Значна увага динамічному аналізу приділяється при проектуванні та експлуатації споруд підвищеної відповідальності [6], а також виконання рекомендацій Eurocode 8 [7, 22]. Рекомендовано робити порівняльний аналіз результатів, отриманих кількома методами. Для врахування взаємодії споруд з грунтовою основою при проектуванні відповідальних об'єктів прийнято застосовувати засоби розрахунку на основі методу скінченних елементів (SCAD, VESNA, PLAXIS, CLASSI, SASSI, ABAQUS, OpenSees та інших) 3 численими динамічними моделями грунтової основи.

Динамічна система «фундамент - грунтова основа» може розглядатись як окремий елемент в складі розрахункової схеми споруди. Питання інтеграції в розрахункові схеми тут не розглядаються.

Основними фізичними явищами при цьому, згідно нормативних документів [11], за умови збереження механічної стійкості основи та площі контакту фундаменту 3 основою 6 жорсткість основи (пружна реакція) та загасання коливань через внутрішне тертя в грунтовому середовищі (матеріальне) та випромінювання енергії при розповсюдженні хвиль (геометричне). У сейсмічному діапазоні частот (що за різними оцінками не перевищує 5-40 Гц) їх за нормативними документами допускається розглядати незалежними від частоти. Зв'язок динамічних переміщень та реакцій без врахування інерційної взаємодії представляється у вигляді комплексних модулів (передаточні функції [12, 13], або обернені до них функції імпедансу $[23,27])$ для заданих розмірів та фізико-механічних властивостей елементів системи. Для будівельних споруд в режимі нормальної експлуатації такі модулі фактично визначаються згідно нормативної методики для динамічної моделі лінійно деформованого грунтового середовища без врахування частоти впливу для основних мод коливань.

Aле складні динамічні властивості системи споруда - грунт (форма підошви, розподіл навантажень, контактні умови, структура грунтової основи) примушують звертати увагу на залежність імпедансних функцій від частоти. Врахування залежності від частоти може досягатись розвитком методу розподілених параметрів для складних систем пружин, демпферів, мас та інших додаткових елементів. Практично зрозумілим, але витратним є спосіб використання передаточних чи обернених ім імпедансних (сил, що викликають одиничні переміщення невагомого штампа в певному напрямку на певній частоті) функцій, що знаходяться експериментальним методом 


\section{سلمس 11}

на місці. Кількість таких досліджень обмежена. Визначення функцій методом математичного моделювання отримало розвиток, але потребує додаткової верифікації на основі експериментальних досліджень (наприклад, внаслідок ефекту підвищеного загасання в модельному пружному середовищі). Знаходження таких функцій, їх обгрунтування та використання в динаміці споруд розглядається в роботах $[3,5,8,9,12,13,16,20$, 21, 23-27] та багатьох інших.

Значний обсяг досліджень в цьому напрямку присвячено дослідженням сейсмостійкості споруд атомних електростанцій. Наприклад, в статті [16] пояснюються результати розрахунків імпедансних функцій шаруватого середовища за допомогою програмних комплексів SASSI та CLASSI (USA).

Імпеданси фундаменту на грунтовій основі визначались у статті [31] з метою досліджень залежності жорсткості та демпфірування від частоти вимушених коливань в діапазоні частот 5-15Гц для натурної моделі споруди 3 залізобетонним фундаментом та надбудовою (сталева рама з регульованою жорсткістю). Імпедансні функції представлено для горизонтальної та обертальної форм коливань при змінній жорсткості рами. Експериментальні результати добре узгоджуються з теоретичними результатами для імпедансу штампа на пружному півпросторі, якщо при розрахунках (SASSI) використовувати дещо збільшене значення модуля зсуву грунтового середовища та спеціально призначати розрахункову швидкість поперечної хвилі.

Вертикальні коливання фундаменту на водонасиченій грунтовій основі можуть суттєво змінюватись в сейсмічному діапазоні частот внаслідок зміни порового тиску на підошву та взаємодії твердої та рідинної фаз у грунтовому матеріалі, що підтверджують відомі дослідження [1, 28]. Оцінка динамічної поведінки такої системи при гармонічних коливаннях штампів 3 проникною та непроникною для порової рідини підошвою на пористопружній насиченій рідиною (ППНР) основі виконувалась на основі розв'язку динамічних контактних задач для штампа в публікаціях [5, $8-10,15,24-26,29,32]$ та ін. методами скінченних елементів, граничних елементів, ортогональних поліномів. У вказаних дослідженнях застосовано досить обгрунтовану динамічну модель ППНР середовища М. Біо, що була представлена в статтях $[17,18]$, ряду іiі застосувань присвячено числені публікації, наприклад, [19], а також матеріали ряду конференцій, наприклад, [32]. Параметри моделі М. Біо враховують щільність матеріалів фаз та їх інерційну взаємодію, пружні характеристики фаз та середовища, в'язкість порової рідини, осереднену пористість твердого скелету та форму пор, фільтраційні характеристики середовища, уточнення для високих частот. Особливими фізичними явищами є розповсюдження двох поздовжніх хвиль, загасання коливань від різниці швидкостей руху пористої пружної твердої та в'язкої стисливої рідинної фаз, а також інерційної взаємодії фаз. Застосування рівнянь М. Біо для аналізу хвильових процесів у грунтовому середовищі 3 помірною інтенсивністю фільтрації в’язкої рідини в системі взаємопов'язаних пор пружного пористого скелету представлено в огляді літератури роботи [3].

Внаслідок ускладнення картини хвильових процесів у грунтовій основі шаруватої структури виникають резонансні явища. Авторами досліджень [2, 14, 16] та ін. теоретично проаналізовано особливості імпедансних функцій для прямокутних та інших штампів на горизонтальношаруватій пружній основі 3 обгрунтуванням теоретичних моделей та особливостей в частотних інтервалах 3 існуванням, зародженнням чи відсутністю різних хвиль в шаруватій основі. Тут розглядаємо крайній випадок - шар ППНР середовища із затисненою тильною гранню, що дозволяє на результатах розрахунків показати резонансні особливості такої основи.

Для моделі плити чи фундаменту прийнято жорсткі смугу чи прямокутний штамп. Контактна умова також вибрана як для крайнього випадку - непроникна для порової рідини (недренована). Деформівні фундаменти також можуть бути розглянуті на основі відповідних моделей [10].

Для смуги 3 непроникною підошвою, що спирається без тертя на поверхню ППНР шару із затисненою нижньою гранню (розрахункову схему показано на рис. 1) методом інтегральних

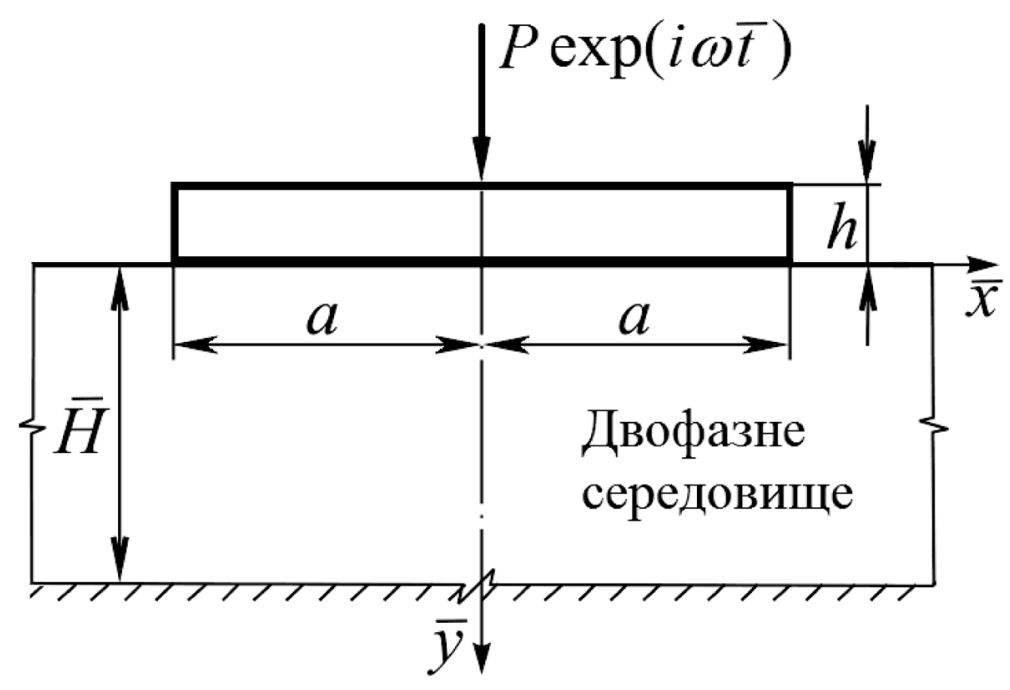

Рис. 1. Жорстка смуга на ППНР шарі 


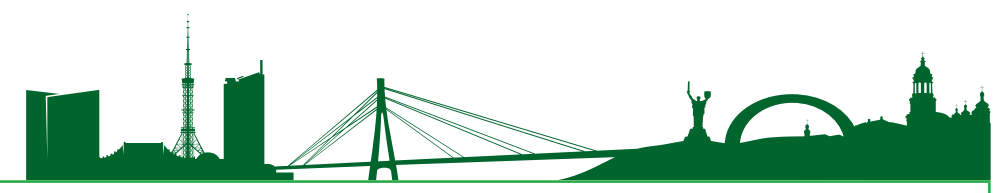

перетворень 3 диференційних рівнянь моделі М. Біо та відповідних граничних умов отримано розв'язок задачі Лемба, а з контактних умов отримано інтегральні рівняння, для розв’язку яких використовується метод ортогональних поліномів [3]. Попередньо було розглянуто закономірності розподілу контактних тисків як від твердого скелету, так і від порової рідини на основі розділення вкладів фаз в аналітичному розв'язку. Теоретичний аналіз ядер інтегральних рівнянь показав, що розподіл ефективних напружень в твердій фазі (логарифмічне ядро) відповідає розподілу з кореневою особливістю по краях, а поровий тиск під підошвою особливостей не має. Представлення невідомих ефективних напружень та порового тиску при вертикальних коливаннях штампа у вигляді нескінченних рядів підібрано у інтегрально-диференційній формі на основі спектральних співвідношень для ортогональних поліномів Чебишова для непроникних для порової рідини жорсткої смуги і прямокутного штампа (на ППНР півпросторі) [3]. Отримано нескінчені системи лінійних алгебраїчних рівнянь (коефіцієнти систем - компоненти переміщень контактної поверхні у вигляді інтегралів від складних функцій) для визначення методом редукції коефіцієнтів рядів для визначення контактних тисків, реакцій фаз та переміщень штампів. Складний вигляд приймають коефіцієнти для шару ППНР в двовимірній постановці [3, $\S 7.3]$ та тривимірній (будуть опубліковані пізніше). В аналітичному розв'язку задачі Аемба, що знаходиться за допомогою комп'ютерних символьних перетворень, враховується повна хвильова картина та визначаються відповідні асимптотики.

На основі числових розрахунків імпедансу проводиться аналіз впливу основних характеристик моделі основи, розміру підошви.

Основним геометричним параметром задачі $\epsilon$ безрозмірна висота шару $H=\bar{H} / a$, де $a$ - півширина смуги (рис. 1), безрозмірна частота визначається як $\zeta=a \omega / c_{2}$, де $\omega$ - кругова частота вимушених коливань, $c_{2}$ - референтна швидкість поперечної хвилі $[17,18]$.

Ключовим параметром ППНР середовища вважається безрозмірний параметр [30]

$$
B=\boldsymbol{b} \frac{a}{c_{2} \rho_{11}},
$$

де $\boldsymbol{b}=\frac{\vartheta^{2} \theta_{0}}{K_{p r}}$ коефіцієнт дисипації двофазного середовища (що враховує внутрішнє тертя при взаємному зміщенні твердої матриці та порової рідини), $\vartheta$ - пористість, $K_{p r}$ проникність (або коефіцієнт фільтрації $\left.k_{f}=K_{p r} \rho_{f} g / \theta_{0}\right), \theta_{0}$ - динамічна в'язкість порової рідини, $\rho_{l l}$ - щільність твердої фази, $\rho_{f}$ - щільність порової рідини, $g$ - прискорення вільного падіння. Використовуємо тут позначки згідно [3].

Результати для прямокутного штампа на ППНР півпростору [3, гл. 7] свідчать про значну (до зміни знаку) залежність від частоти дійсної частини імпедансу (жорсткості) в певному діапазоні частот сейсмічного діапазону внаслідок врахування порового тиску, а для шаруватої основи демонструють складну залежність жорсткості та загасання від частоти коливань.

На рис. 2 показано функції імпедансу для жорсткої смуги (рис. 1) при $H=2$ та $H=8$. Згідно [2] функція приймає нульові значення при частотах
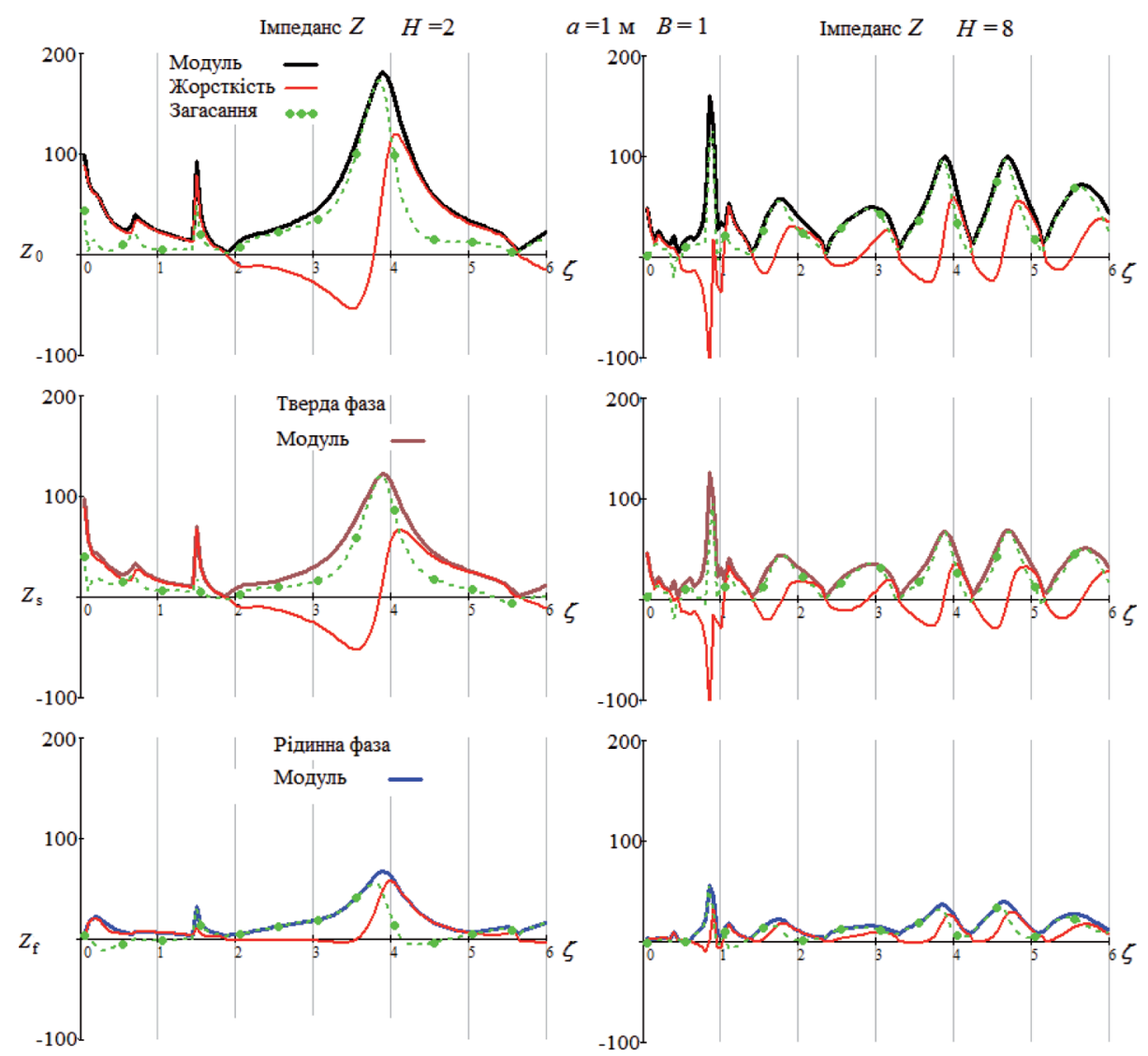

Рис. 2. Імпеданс для жорсткої смуги при $H=2$ та $H=8$; $a=1 \mathrm{м} ; B=1 ; \zeta=0 \div 6$ 


$$
\zeta_{K}=\pi(K+1 / 2) /\left(H \beta_{1}\right), \quad K=0,1,2 \ldots,
$$

де $\beta_{1}=c_{2} / c_{l}(\zeta), c_{l}(\zeta)$ швидкість першої поздовжньої хвилі в двофазному середовищі, на яких в шарі (як і в пружному) зароджуються хвилі нормальних мод, а переміщення теоретично необмежені. В інтервалах між цими частотами жорсткість основи змінюеться досить закономірно, змінюючи від'ємні значення на додатні, як і для моделі півпростору. Екстремальні значення також залежать від частоти.

При частотах нижче виникнення першої нормальної хвилі $\zeta<\zeta_{1}$ основа реагує як пружний шар [2], практично без загасання коливань.

На рис. 3 продемонстровано результати розрахунку для шару $H=4$ при $B=0.1$ та $B=10.0$. У другому випадку взаємодія фаз призводить до значно більшої величини імпедансу, вочевидь за рахунок збільшення внеску рідинної фази. Деякі локальні екстремуми пояснюються відомим 3 теорії [2] ефектом виникнення обернених хвиль в шарі на частотах, попередніх до виникнення нормаль- них мод. Не виключаються похибки розрахунків, що коригуються збільшенням числа членів рядів функцій по ортогональним поліномам та точності оцінки інтегралів в коефіцієнтах системи лінійних алгебраїчних рівнянь.

Представлена модель ілюструє крайній випадок шару із затисненою тильною гранню. Модель основи як пружного шару на півплощині (чи на півпросторі), в якій резонансні частоти подібні, а випромінювання пружних хвиль в півобмежене середовище збільшує загасання, рекомендується використовувати для оцінки динаміки відповідальних споруд [16].

\section{ВИСНОВКИ}

Один 3 методів динамічного аналізу відповідальних споруд - застосування імпедансних чи передаточних функцій частоти, що можуть бути включені до динамічних розрахункових схем. Функції імпедансу для штампа 3 непроникною для порової рідини підошвою на пористопружній шаруватій насиченій рідиною (ППНР) двофазній

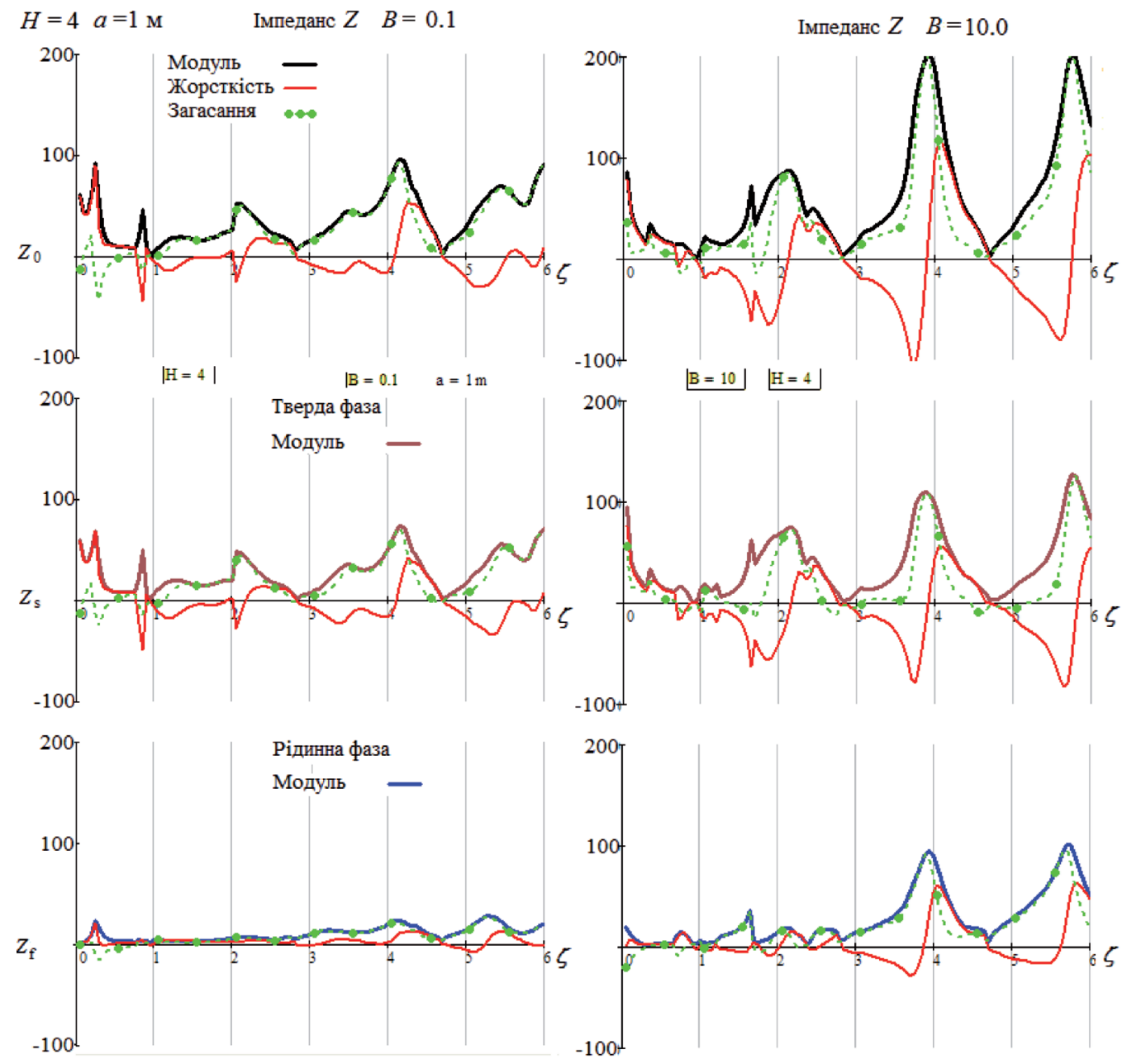

Рис. 3. Імпеданс при $B=0.1$ та $B=10.0 ; H=4 ; a=1$ м; $\zeta=0 \div 6$ 


\section{W 1 A N}

основі визначаються 3 розв'язку динамічної контактної задачі методом ортогональних поліномів, точного розв'язку для переміщень поверхні одношарової основи та програмного забезпечення за геометричними та фізикомеханічними параметрами фундаментів та моделі основи.

На числових прикладах показано, що реакція (імпеданс) ППНР основи відрізняється від реакції пружної моделі. Взаємодія між фундаментом 3 недренованою підошвою та водонасиченим грунтом неодностороння внаслідок змінного тиску стисливої та в'язкої порової рідини в пружній пористій матриці.

Визначено прояви резонансних ефектів одношарової основи в залежності від геометричних параметрів системи фундаментоснова та властивостей матеріалу двофазної основи.

\section{БІБАІОГРАФІЧНИЙ СПИСОК}

1. Абелев М. Ю. Строительство промышленных и гражданских сооружений на слабых во-донасыщенных грунтах / Абелев М. Ю. - М. : Стройиздат, 1983. - 248 с.

2. Бабешко В. А. Динамика неоднородных линейно-упругих сред / В. А. Бабешко, Е. В. Глушков, Ж. Ф. Зинченко. - М. : Наука, 1989. - 343 с.

3. Гомилко А. М. Методы суперпозиции, собственных функций и ортогональных многочленов в граничных задачах теории упругости и акустики / Гомилко А. М., Савицкий О. А., Трофимчук А. Н. - Киев: Наук. думка, 2016. - 436 с. http://itgip.org/ wp-content/uploads/2013/11/GST-2016+a519-01-2017end-titul.pdf.

4. ДБН В.1.1-12-2014 Будівництво у сейсмічних районах України. - Чинні від 2014-10-01. Київ: ДП «Укрархбудінформ». - VI, 110 с.

5. Мишель А. Г. Колебания штампа на двухфазном основании / А. Г. Мишель, С. Г. Шульман // Изв. ВНИИГ им. Б. Е. Веденеева, 1983. - С. 39-41.

6. Особливості визначення навантажень i впливів на об'єкти підвищеного класу відповідальності / Дорофеєв В. С., Егупов К. В., Сгупов В. К., Кендзера О. В., Немчинов Ю. І., Семенова Ю. В., Сорока М. М. // Наука та будівництво. - 2017. - № 4 (14 ). - С. 11-19.

7. Проектування сейсмостійких конструкцій відповідно до Еврокоду 8: практ. посіб. Ч. 1; під ред. проф. Ю.І. Немчинова. - Київ: ТОВ «Український центр реклами та поліграфії», 2015. - 142 с.

8. Савицький О. А. Динаміка фундаменту на шарі водонасиченого грунту / О. А. Савицький // Основи та фундаменти : Міжвідомчий науково-технічний зб.; за заг. ред. І. П. Бойка. - Вип. 37. - Київ: КНУБА, 2015. C. $128-137$.

9. Савицький О. А. Реакція пористо-пружної водонасиченої основи на вимушені коливання невагомого фундамента / Савицький О. А., Трофимчук О. М. // Буд. конструкції : міжвід. наук.-техн. зб. наукових пр. (буд-во). - Вип. 83 : в 2-х кн. : Кн. 1. - Київ: ДП НДІБК, 2016. - С. 305-311.

10. Сеймов В. М. Колебания и волны в слоистых средах / Сеймов В. М., Трофимчук А. Н., Савицкий О. А. - Київ: Наук. думка, 1990. - 224 с.

11. СНиП 2.02.05-87 Фундаменты машин с динамическими нагрузками. - М. : Государственный строительный комитет СССР, 1988.

12. Справочник геотехника. Основания, фундаменты и подземные сооружения / Под общей ред. Ильичева В. А. и Мангушева P. A. - M. : ACB, 2016. - 1040 с.

13. Таранов В.Г. Розрахунково-експериментальні методи визначення рівня коливань й оцінка вібростійкості основ фундаментів машин : автореф. дис. на здобуття наук. ступеня докт. техн. наук : 05.23.02 «Підвалини та фундаменти». - Дніпропетровськ, 1999. $-33 \mathrm{c}$.

14. Трофимчук А. Н. Численное моделирование динамического поведения пористоупругой насыщенной жидкостью среды // Доповіді НАН України, 1998. - № 11. - С. 44-48.

15. Трофимчук А. Н. Динамика пористоупругих насыщенных жидкостью сред / Трофимчук А. Н., Гомилко А. М., Савицкий О. А. - Київ: Наук. думка, 2003. - 230 с.

16. Тяпин А. Г. Горизонтально-слоистое полупространство в качестве модели основания: сравнение различных подходов / Тяпин А. Г. // Сейсмостойкое стр-во. Безопасность сооружений. - 2011. - № 1. - C. 20-26.

17. Biot, M. A. Theory of propagation of elastic waves in fluid-saturated porous solid. I. Lowerfrequency range. J. Acoust. Soc. Amer. 1956. Vol. 28, no. 2. P. 168-178.

18. Biot, M. A. Theory of propagation of elastic waves in fluid-saturated porous solid. II. Higher frequency range. J. Acoust. Soc. Amer. 1956. Vol. 28, no. 2. P. 179-191.

19. Cai, Y. \& Sun, H. Solutions for Biot's poroelastic theory in key engineering fields: Theory and applications. Elsevier, 2017. 178 p. DOI: 10.1016/B978-0-12-812649-3.00001-0.

20. Cottereau, R., Clouteau, D. \& Soize, C. Probabilistic impedance of foundation : impact of the seismic design on uncertain soils. Earthquake Engng Struct. Dyn. 2008. 37. - P. 899-918. 


\section{MU 1 Nom}

21. Dunn, P. W., Hiltunen, D. R. \& Woods R. D. In situ determination of dynamic impedance functions of shallow foundations / Proc. 17 $7^{\text {th }}$ Int. Conf. on Soil Mech. and Geotech. Eng. M. Hamza et al. (Eds.). 2009. IOS Press. P. 20842087. DOI: 10.3233/978-1-60750-031-5-2084.

22. Fardis, M. N., Carvalho, E. C., Fajfar, P. \& Pecker, A. (2015). Seismic design of concrete buildings to Eurocode 8. CRC Press. - 419 p.

23. Gazetas, G. (1991). Formulas and charts for impedances of surface and embedded foundations. J. Geotech. Engng ASCE, vol. 117, no. 9, pp. 1363-1381. DOI: 10.1061/ (ASCE)0733-9410(1991)117:9(1363).

24. Halpern, M. R. \& Christiano, P. (1986). Steady-state harmonic response of a rigid plate bearing on a liquid-saturated poroelastic half-space Earthquake Eng. and Struct. Dyn., vol. 14, no. 3, pp. 439-454. DOI: 10.1002/ eqe. 4290140310

25. He, R. (2017). Dynamic vertical impedance of a submarine strip foundation in ocean engineering : Water wave pressure effect. Ocean Eng., 139, pp. 116-126. DOI: 10.1016/j. oceaneng.2017.04.028.

26. He, R., Wang, L.-Z. - Yu H.Y. (2012). Time harmonic point load and dynamic contact problem of contacting fluid and poroelastic half-spaces. Soil Dynamics and Earthquake Engineering, 36, pp. 20-31. DOI: 10.1016/j. soildyn.2011.12.004.

27. Luco, J. E. \& Wong, H. L. Identification of Soil Properties from Foundation Impedance Functions J. of Geotech. Eng. 1992. 118, 5. P. 780-796. DOI: 10.1061/(ASCE)07339410(1992)118:5(780).

28. Poplin, J. K. Effects of saturation on dynamic response of footings in sand. Technical report S-70-3. U. S. Army Engineer Experiment Station. Vickburg, Mississippi. 1970. 19 p.

29. Senjuntichai, T., Mania, S. \& Rajapakse, R. K. N. D. (2006). Vertical vibration of an embedded rigid foundation in a poroelastic soil. Soil Dyn. Earthquake Engng, Vol. 26, no. 6-7, P. 626-636. DOI: 10.1016/j. soildyn.2006.01.013.

30. Stoll, R. D. \& Bryan, G. M. (1970). Wave attenuation in saturated sediments. J. Acoust. Soc. Amer. 47 (5), Part 2. P. 1440-1447.

31. Tileylioglu, S., Stewart, J. P. \& Nigbor R. L. Dynamic stiffness and damping of a shallow foundation from forced vibration of a field test structure. J. Geotech. Geoenviron. Eng. 2011. - 137. - P. 344-353.

32. Trofymchuk, O. M., Gomilko, O. M. \& Savitsky O. A. Dynamic contact problems for poroelastic liquid-saturated half-space. Proc. of the second Biot conf. on poromechanics, Grenoble, France, 26-28 aug., 2002.
Poromechanics II, Auriault et al (eds). P. 833-838.

\section{REFERENCES}

1. Abelev, M. Iu. (1983). Construction of industrial and civil structures on weak water-saturated soil. M. : Stroiizdat [in Russian].

2. Babeshko, V. A. Hlushkov, E. V. \& Zinchenko, Zh. F. (1989). Dynamics of non-uniform linearly elastic media. M.: Nauka [in Russian].

3. Gomilko, A., Savytskyi, O. \& Trofymchuk, O. (2016). Superposition, Eigenfunctions and Or-thogonal Polynomials Methods in Elasticity and Acoustic Boundary Value Problems. K.: Naukova dumka. Retrieved from http://itgip.org/wp-content/uploads/2013/11/ GST-2016+a5-19-01-2017end-titul.pdf [in Russian].

4. Construction in seismic regions of Ukraine. (2014). DBN B.1.1-12-2014 from 01 October 2014. K.: SE «Ukrarkhbudinform» [in Ukrainian].

5. Mishel A. G. \& Shulman, S. G. (1983). Oscillations of a stamp on the two-phase base. Proc. of the VNIIG, 166, 39-41 [in Russian].

6. Dorofeiev, V. S., Yehupov, K. V., Yehupov, V. K., Kendzera, O. V., Nemchynov Yu. I., Semenova Yu. V. et al. (2017). Features of definition of loadings and impacts on the high responsibility class objects. Science and Construction; 4 (14), 11-19 [in Ukrainian].

7. Nemchynov, Iu. (Ed.). (2015). Design of seismic structures according to Eurocode 8. Practical guidance. Part 1. K.: TOV «Ukrainian Publishing and Advertising Centre» [in Ukrainian].

8. Savytskyi, O. A. (2015). Dynamics of the foundation on a water-saturated soil layer. Bases and foundations: Inter-agency collection of scientific and technical papers. I. P. Boyko (Ed.). Iss. 37, 128-137. K.: KNUCA [in Ukrainian].

9. Savytskyi, O. A. \& Trofymchuk, O. M. (2016). The poroelastic liquid-saturated base response to the weightless foundation forced vibrations. Building constructions: Inter-agency collection of research papers (construction). Iss. 83 : Book 1, 305 311. K.: SE «NDIBK» [in Ukrainian].

10. Seimov, V. M., Trofimchuk, A. N. \& Savitskii O. A. (1990). Vibrations and waves in layered media. K.: Naukova dumka [in Russian].

11. The bases of machines with dynamic loadings (1988). SNiP 2.02.05-87. M.: Gosudarstvennyi stroitelnyi komitet SSSR [in Russian].

12. Geotechnics reference book. Bases, foundations and underground constructions. (2016). V. A. Ilichev, R. A. Mangushev (Eds.). M.: ASV [in Russian]. 


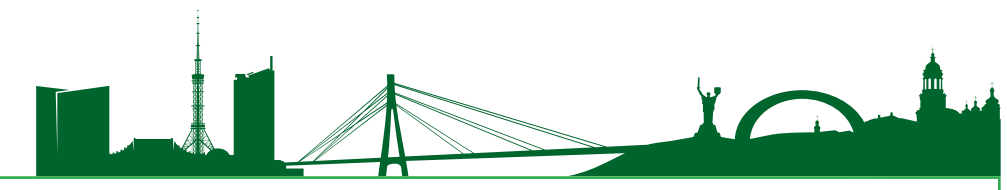

13. Taranov, V. H. (1999). Computationalexperimental methods for the vibrations level determination and vibration strength evaluation for machinary foundations. Extended abstract of the Doctor's thesis (Engineering). Dnipropetrovsk [in Ukrainian].

14. Trofimchuk, A. N. (1998). Numerical modeling of the poroelastic liquid-saturated medium dy-namic behaviour. Reports of the NAS of Ukraine, 11, 44-48 [in Russian].

15. Trofimchuk, A. N., Gomilko, A. M. \& Savitskii, O. A. (2003). Dynamics of the poroelastic liquid-saturated media. K.: Naukova dumka [in Russian].

16. Tiapin, A. G. (2011). The horizontally layered half-space as a foundation model: various ap-proaches comparison. Earthquake engineering. Constructions safety, 1, 20-26 [in Russian].

17. Biot, M. A. (1956). Theory of propagation of elastic waves in fluid-saturated porous solid. I. Lower-frequency range. J. Acoust. Soc. Amer. Vol. 28, no. 2, 168-178 [in English].

18. Biot, M. A. (1956). Theory of propagation of elastic waves in fluid-saturated porous solid. II. Higher frequency range. J. Acoust. Soc. Amer. Vol. 28, no. 2, 179-191 [in English].

19. Cai, Y. \& Sun, H. (2017). Solutions for Biot's poroelastic theory in key engineering fields: Theory and applications. Elsevier, 178 p. DOI: 10.1016/B978-0-12-812649-3.00001-0.

20. Cottereau, R., Clouteau, D. \& Soize, C. (2008). Probabilistic impedance of foundation : impact of the seismic design on uncertain soils. Earthquake Engng Struct. Dyn. 37, 899-918 [in English].

21. Dunn, P. W., Hiltunen, D. R. \& Woods R. D. (2009). In situ determination of dynamic impedance functions of shallow foundations. Proc. $17^{\text {th }}$ Int. Conf. on Soil Mech. and Geotech. Eng. M. Hamza et al. (Eds.). IOS Press. P. 2084-2087. DOI: 10.3233/978-1-60750-031-52084 [in English].

22. Fardis, M. N., Carvalho, E. C., Fajfar, P. \& Pecker, A. (2015). Seismic design of concrete build-ings to Eurocode 8. CRC Press [in English].

23. Gazetas, G. (1991). Formulas and charts for impedances of surface and embedded foundations. J. Geotech. Engng ASCE, vol. 117, no. 9, 1363-1381. DOI: 10.1061/(ASCE)07339410(1991)117:9(1363) [in English].

24. Halpern, M. R. \& Christiano, P. (1986). Steadystate harmonic response of a rigid plate bearing on a liquid-saturated poroelastic half-space. Earthquake Eng. and Struct. Dyn., vol. 14, no. 3, 439-454. DOI: 10.1002/eqe.4290140310 [in English].
25. He, R. (2017). Dynamic vertical impedance of a submarine strip foundation in ocean engineering: Water wave pressure effect. Ocean Eng., 139, 116-126. DOI: 10.1016/j. oceaneng.2017.04.028 [in English].

26. He, R., Wang, L.-Z. \& Yu H.Y. (2012). Time harmonic point load and dynamic contact problem of contacting fluid and poroelastic half-spaces. Soil Dynamics and Earthquake Engineering, 36, 20-31. DOI: 10.1016/j. soildyn.2011.12.004 [in English].

27. Luco, J. E. \& Wong, H. L. (1992) Identification of Soil Properties from Foundation Impedance Functions. J. of Geotech. Eng. 118, 5, 780-796. DOI: 10.1061/(ASCE)07339410(1992)118:5(780) [in English].

28. Poplin, J. K. (1970). Effects of saturation on dynamic response of footings in sand. Technical re-port S-70-3. U. S. Army Engineer Experiment Station. Vickburg, Mississippi [in English].

29. Senjuntichai, T., Mania, S. \& Rajapakse, R. K. N. D. (2006). Vertical vibration of an embedded rigid foundation in a poroelastic soil. Soil Dyn. Earthquake Engng, Vol. 26, no. 6-7, 626-636. DOI: 10.1016/j.soildyn.2006.01.013 [in English].

30. Stoll, R. D. \& Bryan, G. M. (1970). Wave attenuation in saturated sediments. J. Acoust. Soc. Amer. 47 (5), Part 2, 1440-1447 [in English].

31. Tileylioglu, S., Stewart, J. P. \& Nigbor R. L. (2011). Dynamic stiffness and damping of a shallow foundation from forced vibration of a field test structure. J. Geotech. Geoenviron. Eng., 137, 344-353 [in English].

32. Trofymchuk, O. M., Gomilko, O. M. \& Savitsky O. A. (2002). Dynamic contact problems for poroelastic liquid-saturated half-space. Proc. of the second Biot conf. on poromechanics, Grenoble, France, 26-28 aug., Poromechanics II, Auriault et al (eds). P. 833-838 [in English].

Стаття надійшла до редакції 05.09.2018 р. 